Brit. J. industr. Med., 1959, 16, 286.

\title{
THE EFFECT OF DIFFERENT CONCENTRATIONS OF SILICIC ACID AND SILICA DUST ON THE BIOSYNTHESIS OF COLLAGEN IN TISSUE CULTURES
}

\author{
BY \\ M. CHVAPIL and E. HOLEČKOVÁ \\ From the Institute of Industrial Hygiene and Occupational Diseases, and the Laboratory of the Physiology \\ and Pathophysiology of Metabolism, Czechoslovak Academy of Sciences, Prague
}

(RECEIVED FOR PUBLICATION NOVEMBER 3, 1958)

\begin{abstract}
Tissue cultures of fibrogenic cells which form collagen in vitro are a valuable model for quantitative study of the mechanism of this cellular function as well as of problems relevant to pneumoconiosis. We have found a pronounced stimulation of collagen formation in tissue cultures of embryonic chicken lung by silicic acid in a concentration of $0.005 \mathrm{M}$ in the medium. Higher concentrations $(0.01 \mathrm{M})$ were inhibitory as were quartz dust particles of 50 to $70 \mathrm{mg}$. per culture tube, which, during the eight days of incubation, liberated silicic acid in concentrations of an inhibitory order into the culture medium. A low concentration $(0.001 \mathrm{M})$ of silicic acid or of silica dust $\left(5 \mathrm{mg}\right.$.) was ineffectual as was an inert dust $\left(\mathrm{TiO}_{2}\right)$ in a high concentration $(50 \mathrm{mg}$.). Evidence is presented that the stimulatory effect of silicic acid is due to a direct stimulation of postulated enzymatic systems taking part in fibrogenesis. Estimation of dioxyribonucleic acid in the cultures indicated that the number of cells was similar in controls and in cultures with increased and reduced collagen content.
\end{abstract}

The methods of tissue culture have been used in many studies in pneumoconiosis. In none of these studies have the effects of substances stimulating fibrogenesis in vivo been investigated by measuring directly the synthesis of collagenous proteins in vitro, as indirect criteria only have always been used. The phagocytic activity or the degenerative changes as seen in morphological or metabolic impairment of explanted animal cells brought into contact with toxic dust particles have been recorded. Several more or less precise phagocytic indices and dust toxicity tests showing some differences in cellular reactions to inert and toxic dust particles have been designed (Luhr, 1958). In many instances these criteria were shown to be somewhat unspecific and not too reliable (Belt, Friedmann, and King, 1947) though in some recent studies better results were reported (Marks, Mason, and Nagelschmidt, 1956; Marks and Mason, 1956).

Our present experiments are based on the known ability of explanted fibroblastic cells to continue the synthesis of collagenous structures in tissue culture (Porter and Vanamee, 1949). We measured the biosynthesis of collagen in cultured embryonic chick lung tissue quantitatively under the influences of toxic and inert dust particles and of colloidal silicic acid, a potent stimulator of fibrogenesis in other experiments (Siehoff and Antweiler, 1956; Jötten and Klosterkötter, 1958).

\section{Materials}

Tissue Cultures.-Known amounts (about $100 \mathrm{mg}$. wet weight) of lung tissue from 15- to 17-day-old chicken embryos were explanted as fragments in roller tubes on a film of hen plasma in a medium consisting of $40 \%$ tyrode solution, $40 \%$ horse serum, and $20 \%$ native chicken embryonic extract. One hundred units of penicillin and $100 \mu \mathrm{g}$. of streptomycin were added on $1 \mathrm{ml}$. of medium. The cultures were incubated at $38^{\circ} \mathrm{C}$. and rotated 60 times an hour. The medium was not changed during eight days of incubation.

The first determination of collagen was done in incubated controls and then after four and after eight days of incubation, In the last two series of experiments hydroxyproline was determined after eight days of incubation only.

Determination of Collagen.--In saline-washed cultured tissue collagen was determined in individual tubes after acid hydrolysis with $6 \mathrm{~N}$ hydrochloric acid for four hours at $140^{\circ} \mathrm{C}$. In neutralized hydrolysate the amount of hydroxyproline as an indicator of the amount of collagen was determined by the method of Neuman and Logan 
(1950) in Martin's and Axelrod's modification (1953). Every value represents the average of 10 determinations. Dioxyribonucleic acid was isolated by the method of Hull and Kirk (1950) and determined spectroscopically at $2 \cdot 600 \AA$ (Scott, Fraccastoro, and Taft, 1956).

Silica Dust.-Silica dust shown by $x$-ray diffraction to contain $99.8 \%$ of pure $\mathrm{SiO}_{2}$ was used. The particles of the dust prepared by fractionated sedimentation contained practically monodispersed dust of 0.6 to $0.8 \mu$.

Colloidal Silicic Acids. - A dilute solution of sodium metasilicate was neutralized with hydrochloric acid and dialysed against tap water. The concentration of silicic acid was verified gravimetrically as $\mathrm{SiO}_{2}$.

Method of Estimating Solubility of Quartz Particles in Culture Medium.-The solubility of $60 \mathrm{mg}$. quartz particles, $0 \cdot 8 \mu$, was estimated gravimetrically in $10 \mathrm{ml}$. of tissue culture medium (40\% horse serum, $20 \%$ chicken embryonic extract, and $40 \%$ tyrode solution) in roller tubes used in the tissue culture experiments. Eight samples with and four without quartz were rotated for eight days at $37^{\circ} \mathrm{C}$. and then centrifuged through sintered glass.

The gravimetric analysis was performed in $7 \mathrm{ml}$. of the supernatant in porcelain and platinum containers, samples without quartz being used as controls of the organic ash values of culture medium. The final values of silicic acid dissolved in the medium from quartz were obtained by subtracting the organic ash weight in the control tubes without quartz from the weight measured in the tubes with quartz.

Inert Dust.--Inert dust was commercially available as $\mathrm{TiO}_{2}$. To one tissue culture tube, approximately 50 to $70 \mathrm{mg}$. of $\mathrm{SiO}_{2}$ or $\mathrm{TiO}_{2}$ was added. Silicic acid was added in three different concentrations in tyrode solution in the proportion of $0.5 \mathrm{ml}$. to $9.5 \mathrm{ml}$. of medium. Its final concentrations in the medium were $0.001 \mathrm{M}, 0.005 \mathrm{M}$, and $0.01 \mathrm{M}$ respectively. Control cultures had $0.5 \mathrm{ml}$. of tyrode solution only.

\section{Results}

In five independent experiments, we first tested the ability of our culture system to produce collagen under our experimental conditions. The fibrogenic cells of chicken embryonic lung produced collagen, as shown in Fig. 1. The amount of hydroxyproline

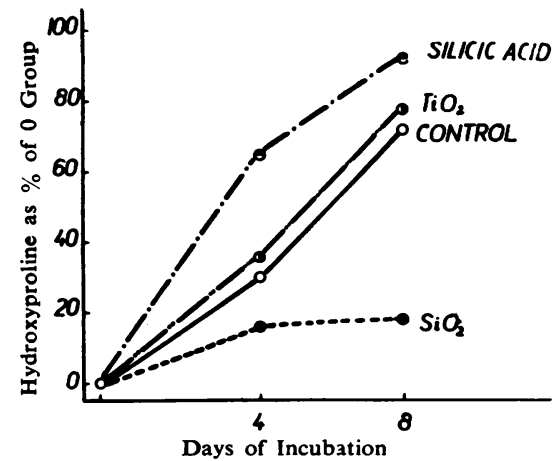

Fig. 1.-The influence of silicic acid, $\mathrm{TiO}_{2}$, and $\mathrm{SiO}_{2}$ on the amount of hydroxyproline in tissue cultures.

The concentration of silicic acid was $0.005 \mathrm{M} ; \mathrm{TiO}_{2}$ and $\mathrm{SiO}_{2}$, 50 to $70 \mathrm{mg}$. per tube.

after eight days of cultivation was significantly higher than before incubation.

Further experiments were designed to study the effects of an inert dust $\left(\mathrm{TiO}_{2}\right)$, a toxic dust $\left(\mathrm{SiO}_{2}\right)$, and a known substance with fibrogenic activity (silicic acid) on the biosynthesis of collagen occurring in our experiment in vitro. There was no difference in the amount of hydroxyproline after eight days of incubation between the control group and the cultures incubated with 50 to $70 \mathrm{mg}$. of $\mathrm{TiO}_{2}$. The cultures incubated with the same amount of the silica dust showed a marked inhibition of collagen formation, and in the cultures incubated with $0.005 \mathrm{M}$ silicic acid the formation of collagen was significantly stimulated (Fig. 1).

Table 1 shows the amount of dioxyribonucleic acid in cultures of all series after eight days of incubation. There was no significant difference in the amount of this substance, indicating that cellular multiplication was the same in all our culture groups. Thus the differences in the amount of collagen are probably due to a difference in the amount of extracellular substances in different experiments rather than to differences in cellular multiplication.

TABLE 1

SUMMARY OF RESULTS

\begin{tabular}{|c|c|c|c|c|c|c|c|c|c|c|}
\hline \multirow[b]{2}{*}{$\begin{array}{c}\text { Duration of Incubation } \\
\text { (days) }\end{array}$} & \multicolumn{2}{|r|}{0} & \multicolumn{3}{|c|}{4} & \multicolumn{5}{|c|}{8} \\
\hline & $\dagger$ & \begin{tabular}{|c|} 
Hydro- \\
xyproline \\
$\mid(\mu \mathrm{g} . / 100 \mathrm{mg})$.
\end{tabular} & + & $\begin{array}{c}\text { Hydro- } \\
\text { xyproline } \\
(\mu \mathrm{g} . / 100 \mathrm{mg} .)\end{array}$ & $\begin{array}{c}\text { Changes in } \\
\% \text { of } \\
\text { Controls in } \mathrm{O}\end{array}$ & $\dagger$ & $\begin{array}{c}\text { Hydro- } \\
\text { xyproline } \\
(\mu g . / \text { in mg. })\end{array}$ & $\begin{array}{c}\text { Changes in } \\
\% \text { of } \\
\text { Control in } \mathrm{O}\end{array}$ & $\dagger$ & (ug./100 mg.) \\
\hline $\begin{array}{l}\text { Controls } \\
\text { Silica dust, } 50 \text { to } 70 \mathrm{mg} \text {. per tube } \\
\text { Silica dust, } 5 \mathrm{mg} \text {. per tube } \\
\text { Silicic acid, } 0.01 \mathrm{M} \\
\text { Silicic acid, } 0.005 \mathrm{M} \\
\text { Silicic acid, } 0.001 \mathrm{M} \\
\mathrm{TiO}_{2}, 50 \text { to } 70 \mathrm{mg} \text {. per tube }\end{array}$ & $\begin{array}{l}E \\
-\end{array}$ & $\begin{aligned} 14 \cdot 8 & \pm 0 \cdot 18 \\
& = \\
& = \\
& =\end{aligned}$ & $\frac{16}{10}$ & $\begin{array}{l}19 \cdot 2 \pm 0.3 \\
17 \cdot 2 \pm 0 \cdot 4 \\
17.5 \pm 0 \cdot 4 \\
24 \cdot 4 \pm 0.4 \\
20 \cdot 1 \pm 0.4\end{array}$ & $\begin{array}{l}30 \\
\frac{16}{18} \\
\frac{65}{36}\end{array}$ & $\begin{array}{r}40 \\
20 \\
8 \\
10 \\
13 \\
10 \\
10\end{array}$ & $\begin{array}{l}25 \cdot 5 \pm 0.4 \\
17 \cdot 5 \pm 0.4 \\
23 \cdot 5 \pm 0.9 \\
17.9 \pm 0.5 \\
28 \cdot 4 \pm 0.3 \\
26 \cdot 0 \pm 0.3 \\
26 \cdot 3 \pm 0.3\end{array}$ & $\begin{array}{l}72 \\
18^{*} \\
59 \\
21^{*} \\
92^{*} \\
76 \\
78\end{array}$ & $\frac{14}{\frac{10}{13}}$ & $\begin{array}{l}103 \pm 3 \cdot 5 \\
104 \pm 3 \cdot 8 \\
\pm \\
108 \pm 3 \cdot 6 \\
99 \pm 4 \cdot 1\end{array}$ \\
\hline
\end{tabular}

*Change significant at $1 \%$ level in relation to control values.

+ No. of roller tubes.

Variability is given by the standard error of the mean. 


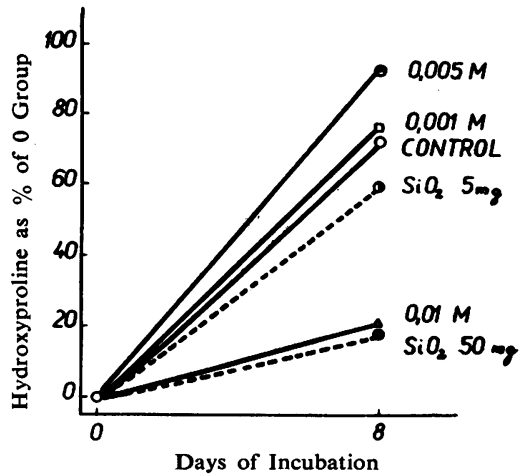

FIG. 2.-The influence of different concentrations of silicic acid and quartz on the amount of hydroxyproline in tissue cultures.

Further experiments were made to elucidate the apparent incongruity of results regarding the stimulation of fibrogenesis brought about by silicic acid and its marked inhibition by silica dust. We therefore investigated in repeated independent experiments the effect of three different concentrations of silicic acid on collagen formation in our tissue cultures (Fig. 2). In a concentration of $0.005 \mathrm{M}$, silicic acid stimulates significantly the production of collagen measured by an increase of hydroxyproline. In a higher concentration of $0.01 \mathrm{M}$ silicic acid has an opposite effect and acts as an inhibitor of collagen synthesis. In the very low concentration of $0.001 \mathrm{M}$, silicic acid has no effect. These results are in agreement with the finding of inhibitory effects of silica dust on collagen synthesis. In the amount used (60 mg.), dust particles of $0.8 \mu$ dissolve in serum during eight days and give a solution of silicic acid, the concentration of which is of the same order as the inhibitory concentration in our experiments.

Table 2 gives the values of silicic acid dissolved in tissue culture medium, and Table 1 summarizes all our results.

If our explanation of the mode of action of crystalline quartz on the fibrillogenetic activity of fibroblasts be correct, lower $\mathrm{SiO}_{2}$ concentrations would not inhibit the biosynthesis of collagen in tissue culture. We therefore investigated the synthesis of hydroxyproline containing substances in cultures with $5 \mathrm{mg}$. and $50 \mathrm{mg}$. of crystalline $\mathrm{SiO}_{2}$ added to the medium and in untreated controls. In control cultures there was an increase of $71 \%$ of unincubated blanks; in cultures with $5 \mathrm{mg}$. of $\mathrm{SiO}_{2}$, there was no significant difference from control values $(53 \%$ increase of collagen) whereas in the cultures treated with $50 \mathrm{mg}$. of $\mathrm{SiO}_{2}$ the synthesis of collagen was again significantly inhibited $(P<0,0 \cdot 1)$ (Fig. 2). A further demonstration of this hypothesis is the ineffectiveness of silica dust in low concentration (5 mg. per culture tube).

\section{Discussion}

The first quantitative study of collagen synthesis in tissue culture was published by Gerarde and Jones (1953). These authors reported a great $(800 \%)$ increase of collagen after 12 days of cultivation differing somewhat from the conditions in our experiments. Recently, Hulliger, James, and Allgöwer (1957) obtained a $100 \%$ increase of collagen in tissue cultures after 10 days of cultivation. These results are in good agreement with our finding of an $80 \%$ increase of collagen after eight days of cultivation. In absolute values, this represents an average of $15 \mu \mathrm{g}$. of hydroxyproline in $100 \mathrm{mg}$. of wet lung tissue of 15- to 17-day-old chicken embryos and $25 \mu \mathrm{g}$. after eight days of cultivation.

The ability of explanted fibrogenic cells to produce collagenous proteins in tissue culture is thus established, and this experiment in vitro may serve as a valuable model for the study of factors which stimulate collagen formation. Such a technique may be used with advantage for investigations concerned with the mechanism of collagen synthesis as well as for research relevant to the fundamental problems of pneumoconiosis.

In this part of our work we used the tissue culture experiments to study direct effects of silica dust and silicic acid on the formation of collagen. In an appropriate concentration, silicic acid has a pronounced stimulating effect on collagen synthesis in explanted lung tissue. In a high concentration, silicic acid acts as an inhibitor of this function of fibrogenic cells while in a low concentration its fibrogenic activity is lost. James and Marks (1956) call attention to the fact that silicic acid in concentrations higher than 1.67 to $2.67 \mathrm{M}$ is in solution in a polydispersed

TABLE 2

SOLUBILITY OF QUARTZ PARTICLES IN CULTURE MEDIUM

\begin{tabular}{|c|c|c|c|c|c|}
\hline & \multicolumn{5}{|c|}{ Amounts of $\mathrm{SiO}_{2}$ in $\mathrm{mg} . / 10 \mathrm{ml}$. of Medium } \\
\hline & I & II & III & IV & Average \\
\hline $\begin{array}{l}\text { Porcelain crucible } \\
\text { Platinum crucible }\end{array}$ & $\begin{array}{l}25 \cdot 4 \\
29 \cdot 2\end{array}$ & $\begin{array}{l}26 \cdot 6 \\
26 \cdot 4\end{array}$ & $\begin{array}{l}23 \cdot 0 \\
26 \cdot 2\end{array}$ & $\begin{array}{l}27.9 \\
22.5\end{array}$ & $\begin{array}{l}25.7 \pm 1.04 * \\
26.2 \pm 1.37^{*}\end{array}$ \\
\hline
\end{tabular}

$26 \mathrm{mg}$. of $\mathrm{SiO}_{2}$ corresponds to $4.3 \times 10^{-2} \mathrm{M}$ silicic acid.
*S.E. of the mean. 
state, while in lower concentrations it dissociates into monomeric form. We did not attempt to analyse these problems in the work reported here. Our experiments amassed evidence that the inhibitory effects of a given amount of silica dust on collagen synthesis in tissue culture are due to its solubility in a serum medium, where a concentration of silicic acid shown to act as an inhibitor of collagen synthesis is formed by dissolution of the dust during the incubation period. Further known toxic effects of ingested silica particles on phagocytic cells are not considered in the present study, showing clearly the ability of silicic acid in sufficient concentration to suppress collagen production with no particles present. An inert dust $\left(\mathrm{TiO}_{2}\right)$ in the same amount per culture tube as the silica dust was ineffective.

The increase of collagen is not due to an increase in the number of cells, for the amount of dioxyribonucleic acid indicating the extent of cellular multiplication, does not differ from the controls. The same is true for the experiments where an inhibition of collagen synthesis under the influence of a high concentration of silicic acid or of silica dust was found without a change in the amount of dioxyribonucleic acid.

Our results lead us to the conclusion that silicic acid in adequate concentration stimulates the activity of some enzymatic system (or systems) of the cells which take part in collagen synthesis and was postulated by Jackson, Fitton, and Smith, (1955) and by Jackson and Smith $(1955,1958)$ on the basis of their experimental work. If this hypothesis be correct our results would bring the first evidence of a stimulation of enzymatic activity by silicic acid. The nature of this activity is unknown, as most of the enzymes tested are inhibted by this substance (Kind, King, Pash, Roman, and Schmidt, 1954; King, Schmidt, Roman, and Kind, 1956; James and Marks, 1956).

\section{REFERENCES}

Belt, T. H., Friedmann, L., and King, E. J. (1947). J. Path. Bact., 59, 159.

Gerarde, H. W., and Jones, M. (1953). J. biol. Chem., 201, 553.

Hull, W., and Kirk, P. L. (1950). J. gen. Physiol., 33, 327.

Hulliger, L., James, D. W., and Allgöwer, M. (1957). Experientia (Basel), 13, 454.

Jackson, S., Fitton, and Smith, R. H. (1955). In Symp. Soc. Exp. Biol. IX: Fibrous Proteins and Their Biological Significance, p. 89. University Press, Cambridge.

- and Smith, R. H. (1958). In Recent Advances in Gelatin and Glue Research, Proc. Conf., Cambridge, 1957, ed. G. Stainsby Glue Research, Proc. Conf., Cam

James, D. M., Mergamon Press, London. Jarks, J. (1956). J. Hyg. (Lond.), 54, 342.

Jötten, K. W., and Klosterkötter, W. (1958). Medizinische, p. 1075.

Kind, P. R. U.,, King, E. J., Pash, V., Roman, W., and Schmidt, E. (1954). Biochem. J., 56, XLV.,'

King, E. J., Schmidt, E., Roman, W., and Kind, P. R. N. (1956). Enzymologia, 17, 341 .

Luhr, H. G. (1958). Arch. Gewerbepath. Gewerbehyg., 16, 355.

Marks, J., Mason, M. Ann (1956). Brit. J. industr. Med., 13, 192. , and Nagelschmidt, G. (1956). Ibid., 13, 187.

Martin. C.'J., and Axelrod, A. E. (1953). Proc. soc. exp. Biol. (N.Y.), 83, 461 .

Neuman, R. E., and Logan, M. A. (1950). J. biol. Chem., 186, 549.

Porter, K. R., and Vanamee, P. (1949). Proc. soc. exp. Biol. (N.Y.), $71,513$.

Siehoff, F., and Antweiler, H. (1956). Arch. Gewerbepath. Gewerbehyg., 15, 158.

Scott, J. F., Fraccastoro, A. P., and Taft, E. B. (1956). J. Histochem. 